\title{
Nitrogen and phosphorus uptake efficiency in Indian mustard cultivated during three growth cycles in a copper contaminated soil treated with biochar
}

\section{Maria Isidória Silva Gonzaga ${ }^{*}$ (D) Danyelle Chaves Figueiredo de Souza ${ }^{2}$ André Quintão de Almeida ${ }^{3}$ Cheryl Mackowiak ${ }^{4}$ Idamar da Silva Lima ${ }^{1}$ José Carlos de Jesus Santos $^{1}$ Raquel Santos de Andrade ${ }^{1}$}

${ }^{1}$ Departamento de Engenharia Agronômica, Universidade Federal de Sergipe (UFS), 49100-000, São Cristóvão, SE, Brasil. E-mail: mariaisisilva@gmail.com. *Corresponding author.

${ }^{2}$ Pós-graduação em Recursos Hídricos, Universidade Federal de Sergipe (UFS), São Cristóvão, SE, Brasil.

${ }^{3}$ Departamento de Engenharia Agrícola, Universidade Federal de Sergipe (UFS), São Cristóvão, SE, Brasil.

${ }^{4}$ North Florida Research and Education Center, University of Florida, Quincy, 32351, United States.

\begin{abstract}
Biochar has been used worldwide as an efficient soil amendment due to its beneficial interaction with soil particles and nutrients; however, studies on the effect of biochar on the availability of nutrients such as $N$ and $P$ in tropical soils are still missing. The objective of the study was to evaluate the effect of different types and doses of biochars on the concentration and uptake of $N$ and $P$ in Indian mustard plants (Brassica juncea L.) grown in a Cu contaminated soil during three successive growth cycles. The greenhouse experiment was set up as randomized block design in a $3 \times 3$ factorial scheme, with 3 types of biochars (coconut shell, orange bagasse and sewage sludge) and three rates of application $\left(0,30\right.$ and $\left.60 t \mathrm{~h}^{-1}\right)$, and 4 replicates. Biochar increased plant growth by approximately 30 to $224 \%$; however, the orange bagasse biochar was the most effective. Biochar reduced plant $N$ concentration in approximately 15-43\%, regardless of the rate of application, indicating the need to carefully adjust $N$ fertilization. In the last growth cycle, biochar from coconut shell and orange bagasse improved the $N$ uptake efficiency suggesting a better amelioration effect with ageing in soil. Biochar did not affect P nutrition in Indian mustard to a great extent; however, it significantly decreased the N:P ratio in the plant.

Key words: biochar, pyrogenic carbon, copper contamination, plant nutrition, Brassica juncea.
\end{abstract}

Eficiência de absorção de nitrogênio e fósforo em mostarda indiana cultivada por três ciclos sucessivos em um solo contaminado com cobre e tratado com biocarvão

RESUMO: O biocarvão tem sido usado mundialmente como um eficiente insumo agrícola devido à sua interação benéfica com as partículas e os nutrientes do solo. Contudo, seu efeito na disponibilidade de nutrientes como $\mathrm{N}$ e $\mathrm{P}$ em solos tropicais tem sido pouco investigado. $O$ objetivo do estudo foi avaliar o efeito de diferentes tipos e doses de biocarvão na concentração e na eficiência de absorção de $N$ e $P$ em plantas de mostarda indiana (Brassica juncea L.) cultivadas em solo contaminado com cobre, em três ciclos sucessivos de cultivo. O estudo foi desenvolvido em delineamento de blocos casualizados, em esquema fatorial 3x3, em casa de vegetação, com três tipos de biocarvão (casca de coco, bagaço de laranja e lodo de esgoto) e três doses $\left(0,30\right.$ e $\left.60 t \mathrm{ha}^{-1}\right)$. Todos os biocarvões aumentaram o crescimento das plantas, com variação de 30 a 224\%. No entanto, o biocarvão de bagaço de laranja foi o mais eficiente. A presença de biocarvão reduziu a concentração de $N$ nas plantas em torno de 14 a 43\%, independente da dose aplicada, indicando a necessidade de monitoramento mais cuidadoso da fertilização nitrogenada. Os biocarvões de casca de coco e bagaço de laranja melhoraram a eficiência da planta na absorção de $N$ no terceiro ciclo de cultivo, indicando melhor efeito com o tempo de contato como o solo. O uso de biocarvão teve pouca influência na nutrição fosfatada na mostarda indiana, mas diminuiu significativamente a relação $N: P$.

Palavras-chave: biocarvão, carbono pirogênico, contaminação com cobre,nutrição de planta, Brassica juncea.

\section{INTRODUCTION}

Use of biochar as soil amendment has been considered as an environmentally friendly strategy to improve soil fertility while reducing negative impacts caused by the inappropriate disposal of organic wastes. Effect of biochar on soil fertility is believed to be related to its high porosity, surface area and CEC, which increase the soil retention capacity for water and nutrients. However, many other factors such as the biochar liming effect and the presence of a variety of oxygenated functional groups make it difficult to predict all the benefits of biochar to plant growth and productivity (NGUYEN et al., 2017), specially the 
effect of biochar on the behavior of $\mathrm{N}$ and $\mathrm{P}$ in the soil and in the plant (KAMMANN et al., 2015; DEENIK \& COONEY, 2016).

Nitrogen and $\mathrm{P}$ are very important plant macronutrients and their availability in soil as well as their interaction limits plant growth (GROOT et al., 2003). Studies about the effect of biochar on the availability of $\mathrm{N}$ in soil have generated many contradictory results varying from positive, negative and even no effect (CLOUGH et al., 2013; RAHMAN et al., 2013; NGUYEN et al., 2017). The same different outcomes are observed during the evaluation of the effects of biochar on plant $\mathrm{N}$ absorption (SAARNIO et al., 2013). Additionally, biochar has also been related to changes in the P cycle in highly weathered acidic soils (ABDELHAFEZ et al., 2017), where the availability of $\mathrm{P}$ is mostly controlled by the presence of reactive $\mathrm{Al}$ and $\mathrm{Fe}$ surfaces that present high affinity for $\mathrm{P}$ at low soil $\mathrm{pH}$, causing $\mathrm{P}$ to be chemically adsorbed and leading to low agronomic P use efficiency (ANTONIADIS et al., 2015). In that case, the liming effect of biochar to certain extent can increase $\mathrm{P}$ availability by reducing $\mathrm{P}$ adsorption (VANEK \& LEHMANN, 2015).

Plant growth inmetal contaminated soils can be seriously impaired not only by high concentrations of heavy metals but also by availability of nutrients and nutritional status, including heavy metal tolerant ones such as Indian mustard (MOURATO et al., 2015) that are often used as food crop as well as to remediate contaminated soils (RODRÍGUEZ-VILA et al., 2015). Therefore, the objective of this study was to evaluate the concentration of $\mathrm{N}$ and $\mathrm{P}$ in plant tissue as well as $\mathrm{N}$ and $\mathrm{P}$ use efficiency in Indian mustard plants cultivated in a copper contaminated soil and treated with different types and doses of biochar, during three successive growth cycles.

\section{MATERIALS AND METHODS}

\section{Soil and biochar characterization}

Soil was collected in the $0-0.20 \mathrm{~m}$ layer from a

fallow field at the Universidade Federal de Sergipe (UFS) experimental station, Northeast Brazil (about S $10^{\circ} 55^{\prime}$ 46 "; N $\left.37^{\circ} 06^{\prime} 13^{\prime \prime}\right)$. The soil was classified as Argissolo Amarelo (SANTOS et al., 2013), (Ultisol, according to SOIL SURVEY STAFF (2014)) and presented the following characteristics: $\mathrm{pH}$ : 4.64, organic carbon: $11.6 \mathrm{~g}$ $\mathrm{kg}^{-1}$, CEC: $1.88 \mathrm{cmol} \mathrm{kg}^{-1}$, P: $1.82 \mathrm{mg} \mathrm{kg}^{-1}, \mathrm{~K}: 25.4 \mathrm{mg} \mathrm{kg}^{-1}$, total $\mathrm{Cu}: 100 \mathrm{mg} \mathrm{kg}^{-1}$. Physical properties were: Sand: $72 \%$, Silt: 13\%, Clay: 15\% (DAY, 1965).

The biochars were produced from coconut shell, orange bagasse and sewage sludge in a slow pyrolysis reactor, at $500^{\circ} \mathrm{C}$. Biochar was ground, sieved to $2 \mathrm{~mm}$ particle size and evaluated through proximate analysis (Ash, volatile matter and fixed $\mathrm{C}$ ), and ultimate analysis (C, N, H and $\mathrm{O}$ ) according to the American Society for Testing and Materials (ASTM) D1752-84. Elemental composition of $\mathrm{C}, \mathrm{H}$, and $\mathrm{N}$ was determined using an elemental analyzer. Cation exchange capacity was determined by ammonium acetate method (THOMAS, 1982). Biochar $\mathrm{pH}$ and electrical conductivity were also determined. Biochar characteristics are presented in table 1.

\section{Experimental set up}

The experiments were carried out in a greenhouse environment at a temperature of $28^{\circ} \mathrm{C}$ and as a completely randomized design in a $3 \times 3$ factorial scheme, with 4 replicates. Treatments were three types of biochar (coconut shell-CSB; orange bagasse - OBB; and sewage sludge - SSB) and three rates of application $\left(0,30\right.$ and $\left.60 \mathrm{tha}^{-1}\right)$. Experimental units were comprised of 5L plastic pots. Soil was spiked with copper sulfate three months prior the experiment. Biochar $(37,5 \mathrm{~g}$ or $75 \mathrm{~g})$ was mixed with the contaminated soil $(3.5 \mathrm{~kg})$, transferred to pots, watered to field capacity and incubated during one week before planting in order to equilibrate. One healthy Indian Mustard seedling with four leaves was transferred to each pot and allowed to grow for 60 days. Plants were watered throughout the study to keep the soil at approximately $70 \%$ of its field capacity. Indian mustard plants were cultivated for three successive growth cycles (April to June; June to August; August to October, 2016). At the beginning of each growth

Table 1 - Characteristics of biochars.

\begin{tabular}{lcccccccc}
\hline \multirow{2}{*}{ Biochar } & VM & Ash & FC & C & N & P & pH \\
\hline CSB & 15.8 & 10.8 & 67.2 & 79.5 & 0.42 & 0.02 & 10.6 & $\mathrm{cmolc}^{-1}$ \\
OBB & 17.6 & 16.1 & 58.7 & 72.3 & 2.55 & 0.52 & 10.0 \\
SSB & 26.0 & 36.0 & 34.1 & 43.0 & 6.80 & 1.06 & 7.30 \\
\hline
\end{tabular}


cycle, $1 \mathrm{~g}$ of mineral fertilizer (osmocote:14-14-14) was applied to each pot.

Before harvesting, chlorophyll content of the mid-section, fully expanded leaves was measured, using a non-modulated fluorimeter OS-30P model (ADC BioScientific Ltd., UK). After each harvesting, plants were washed with tap water, rinsed with DI water and dried in a $60^{\circ} \mathrm{C}$ oven for approximately 48 hours, weighed for the determination of the dry biomass and ground to pass through a $2 \mathrm{~mm}$ screen for $\mathrm{N}$ and $\mathrm{P}$ analysis. Samples were digested in a hot block digestion system, according to the TKN protocol for $\mathrm{N}$ determination (BREMNER, 1996). Total $P$ concentration in plant samples was determined in the TKN extracts using the molybdenum blue method (MURPHY \& RILEY 1962). Soil samples were collected at the beginning of each growth cycle from each experimental pot, dried, sieved to $2 \mathrm{~mm}$ screen and analyzed for $\mathrm{pH}, \mathrm{EC}$, organic $\mathrm{C}$ and concentration of extractable $\mathrm{Cu}, \mathrm{N}, \mathrm{P}, \mathrm{K}$ and $\mathrm{Na}$. Soil $\mathrm{pH}$ was determined in a 1:5 (w/w) biochar:water ratio after $1.5 \mathrm{~h}$ shaking in a reciprocating shaker and $1 \mathrm{~h}$ equilibration. Concentrations of extractable $\mathrm{Cu}, \mathrm{P}, \mathrm{K}$ and $\mathrm{Na}$ were determined following extraction with $1 \%$ citric acid (WU et al., 2004). Soil plant available $\mathrm{N}$ was extracted with $2 \mathrm{M} \mathrm{KCl}$. The uptake efficiency of $\mathrm{N}$ or $\mathrm{P}$ was calculated by dividing $\mathrm{N}$ or $\mathrm{P}$ uptake by the root biomass dry weight (GOOD et al., 2004).

\section{Statistical analysis}

Statistical analysis was performed separately on each crop cycle because the experiments were not run concurrently. Results are reported as the means of four replicates. Data obtained were subjected to two-way Analysis of Variance (ANOVA) for assessing the significance of quantitative changes in the variables as a result of biochar treatments using SISVAR software package (FERREIRA, 2011). When a significant difference was observed between treatments, multiple comparisons were made by the Tukey-test at $\mathrm{P}<0.05$.

\section{RESULTS AND DISCUSSION}

\section{Effect of biochar in plant biomass}

Application of biochar significantly $(\mathrm{P}<0.05)$ increased plant biomass in all growth cycles (Table 2); however the effects varied with biochar type and rates of application. In the first and third growth cycles, biochar from coconut shell increased plant biomass by approximately 50 and $32 \%$, regardless of the rate of application. In the second growth cycle, the increase was according to the rate of application, being $100 \%\left(30 \mathrm{tha}^{-1}\right)$ and $224 \%\left(60 \mathrm{tha}^{-1}\right)$. The OBB was more effective in increasing plant biomass in all growth cycles, varying from $168 \%$ (GC1), 148-191\% $\left(\mathrm{GC} 2,30 \mathrm{tha}^{-1}\right.$ and $60 \mathrm{tha}^{-1}$, respectively) and $60 \%$

Table 2 - Biomass and concentration of $\mathrm{N}$ and $\mathrm{P}$ in the shoot of Indian mustard plants after growing in the copper contaminated soil treated with biochar from coconut shell (CSB), orange bagasse (OBB) and sewage sludge (SSB). Means followed by same letter (uppercase in a row; lowercase in a column) are not significantly different $(\mathrm{P}<0.05)$ for comparisons made within each crop cycle ( $n=4$ per treatment)

\begin{tabular}{|c|c|c|c|c|c|c|c|c|c|}
\hline \multirow{2}{*}{ Rate of application } & CSB & OBB & SSB & CSB & OBB & SSB & CSB & OBB & SSB \\
\hline & \multicolumn{3}{|c|}{----------Growth cycle 1---------- } & \multicolumn{3}{|c|}{-----------Growth cycle 2------------ } & \multicolumn{3}{|c|}{------------Growth cycle 3------------- } \\
\hline \multicolumn{10}{|c|}{ 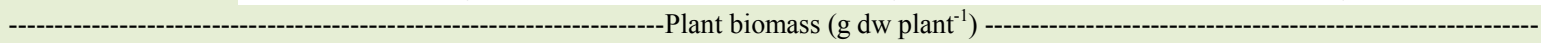 } \\
\hline 0 & $1.28 \mathrm{Ab}$ & $1.28 \mathrm{Ab}$ & $1.28 \mathrm{Aa}$ & $2.74 \mathrm{Ac}$ & 2.79Ac & $2.79 \mathrm{Ab}$ & $3.80 \mathrm{Ab}$ & $3.60 \mathrm{Ab}$ & $3.60 \mathrm{Ac}$ \\
\hline 30 & $1.97 \mathrm{Ba}$ & $3.96 \mathrm{Aa}$ & $1.05 \mathrm{Ca}$ & $5.48 \mathrm{Bb}$ & $6.92 \mathrm{Ab}$ & $7.00 \mathrm{Aa}$ & $5.09 \mathrm{Aa}$ & $5.87 \mathrm{Aa}$ & $5.37 \mathrm{Ab}$ \\
\hline 60 & $1.94 \mathrm{Ba}$ & $2.92 \mathrm{Aa}$ & $1.34 \mathrm{Ba}$ & 8.90Aa & $8.13 \mathrm{Aa}$ & $6.92 \mathrm{ba}$ & $4.97 \mathrm{Ca}$ & $5.65 \mathrm{Ba}$ & $6.80 \mathrm{Aa}$ \\
\hline \multicolumn{10}{|c|}{ 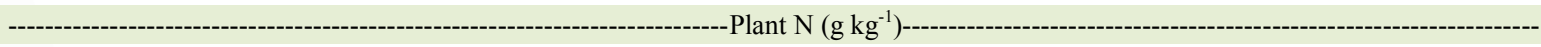 } \\
\hline 0 & $27.8 \mathrm{Aa}$ & $27.8 \mathrm{Aa}$ & $27.8 \mathrm{Aa}$ & $28.0 \mathrm{Aa}$ & $28.0 \mathrm{Aa}$ & $28.0 \mathrm{Aa}$ & 46.9Aa & $46.9 \mathrm{Aa}$ & 46.9Aa \\
\hline 30 & $23.4 \mathrm{Bb}$ & $21.3 \mathrm{Bb}$ & $29.1 \mathrm{Aa}$ & $18.3 \mathrm{Ab}$ & $15.1 \mathrm{Ab}$ & $16.8 \mathrm{Ab}$ & $33.9 \mathrm{Ab}$ & $34.5 \mathrm{Ab}$ & $32.6 \mathrm{Ab}$ \\
\hline 60 & $23.9 \mathrm{Ab}$ & $19.7 \mathrm{Bb}$ & $29.5 \mathrm{Aa}$ & $15.2 \mathrm{Ab}$ & $16.5 \mathrm{Ab}$ & $17.9 \mathrm{Ab}$ & $37.2 \mathrm{Ab}$ & $31.9 \mathrm{Bb}$ & $34.4 \mathrm{ABb}$ \\
\hline \multicolumn{10}{|c|}{ - } \\
\hline 0 & $3.14 \mathrm{Ab}$ & $3.14 \mathrm{Ab}$ & $3.14 \mathrm{Aa}$ & $3.88 \mathrm{Aa}$ & $3.88 \mathrm{Aa}$ & $3.88 \mathrm{Aa}$ & $5.20 \mathrm{Aa}$ & 5.18Aa & $5.20 \mathrm{Aa}$ \\
\hline 30 & $5.42 \mathrm{Aa}$ & $5.04 \mathrm{ABa}$ & $3.97 \mathrm{Ba}$ & $3.34 \mathrm{Aa}$ & $3.98 \mathrm{Aa}$ & $4.03 \mathrm{Aa}$ & $4.92 \mathrm{Ba}$ & $5.93 \mathrm{Aa}$ & $4.96 \mathrm{Ba}$ \\
\hline $\mathrm{a} 60$ & $3.94 \mathrm{Ab}$ & $3.04 \mathrm{Ab}$ & $3.40 \mathrm{Aa}$ & $3.59 \mathrm{Aa}$ & 4.40Aa & $4.08 \mathrm{Aa}$ & $5.30 \mathrm{Aa}$ & $5.72 \mathrm{Aa}$ & $5.40 \mathrm{Aa}$ \\
\hline \multicolumn{10}{|c|}{ 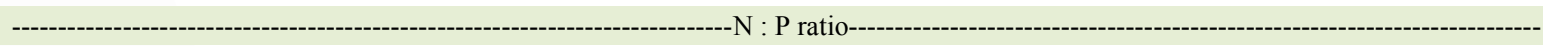 } \\
\hline 0 & $7.23 \mathrm{Aa}$ & $7.23 \mathrm{Aa}$ & 7.23Aa & $8.22 \mathrm{Aa}$ & 8.22Aa & $8.22 \mathrm{Aa}$ & 9.40Aa & $9.07 \mathrm{Aa}$ & $9.03 \mathrm{Aa}$ \\
\hline 30 & $5.10 \mathrm{Ab}$ & $3.97 \mathrm{Bb}$ & $4.65 \mathrm{ABb}$ & $4.74 \mathrm{Bc}$ & $4.29 \mathrm{Bc}$ & $6.88 \mathrm{Ab}$ & $7.50 \mathrm{Ab}$ & $5.83 \mathrm{Bb}$ & $6.70 \mathrm{ABb}$ \\
\hline 60 & $4.36 \mathrm{Ac}$ & $3.83 \mathrm{Ab}$ & $4.42 \mathrm{Ab}$ & $6.37 \mathrm{Bb}$ & $6.50 \mathrm{Bb}$ & 8.38Aa & $7.05 \mathrm{Ab}$ & $5.57 \mathrm{Bb}$ & $6.41 \mathrm{ABb}$ \\
\hline
\end{tabular}


(GC3). The effect of the SSB on plant biomass was only observed in the GC2 (150\%) and GC3 (50\% and $90 \%$, for $30 \mathrm{tha}^{-1}$ and $60 \mathrm{tha} \mathrm{h}^{-1}$, respectively), confirming the beneficial effect of this biochar as reported by SILVA et al. (2017). Biochar effect in increasing plant growth was probably due to the amelioration effect in the contaminated soil by increasing soil $\mathrm{pH}$ and the availability of some nutrients such as $\mathrm{P}$ and $\mathrm{K}$ which was confirmed in the study of DEENIK \& COONEY (2016) when corn cob and sewage sludge biochar was applied to an oxisol. The authors observed that biochars in combination with fertilizer doubled plant growth compared to the control in the first crop cycle produced no significant effect in the second cycle, and more than tripled plant growth for the sewage sludge biochar in the third cycle. In the present study, plants presented poor growth in the first cycle due to a problem in the greenhouse.

\section{Effect of biochar in N nutrition}

The increase in plant biomass caused by the presence of biochar was not followed by an increase in the concentration of $\mathrm{N}$ in the plant aboveground part, which varied from $15.1-46.9 \mathrm{~g} \mathrm{~kg}^{-1}$. Considering that the concentration of $\mathrm{N}$ commonly ranges from 23.9 - $55.1 \mathrm{~g} \mathrm{~kg}^{-1}$ for plants of the Brassica genus, the presence of biochar, especially in the GC2, caused a reduction in $\mathrm{N}$ concentration below the lower limit in most plants. In fact, all biochars reduced plant $\mathrm{N}$ (Table 2) in approximately $15-43 \%$, regardless of the rate of application, which could be observed by the chlorotic appearance of leaves. Considering that all the plants were equally fertilized with $\mathrm{N}$, the yellow discoloring of the leaves observed in the treatments with biochar is supposed to be related to the effect of biochar on the fate of $\mathrm{N}$ and not to the effect of the high $\mathrm{Cu}$ concentration in the contaminated soil. Therefore, $\mathrm{N}$ fertilization in soils treated with biochar should be a concern. Reduction in plant $\mathrm{N}$ concentration due to biochar was also confirmed by the reduction in the chlorophyll content (Table 3) and could have been a result of the improved growth and consequently increased demand for this essential macronutrient. ARGENTA et al. (2004) also reported good correlations between plant $\mathrm{N}$ and Chlorophyll content in maize plants.

Additionally, it was reported that during the ageing of biochar in the soil, $\mathrm{NO}_{3}-\mathrm{N}$ chemisorption through $\mathrm{H}$-bonding may be enhanced because biochar becomes more hydrophilic (HAMMES \& SCHMIDT, 2009); however, in the present study, the evaluation of $\mathrm{N}$ availability through $\mathrm{KCl}$ extraction showed little influence of the biochars (Table 4), except in the OBB treatment which significantly decreased extractable $\mathrm{N}$. This effect could also be related to the increase in $\mathrm{pH}$ when the OBB was applied to soil (Table 4), leading to $\mathrm{N}$ loss through volatilization (NGUYEN et al., 2017). Therefore, different biochars may likely influence different mechanisms of $\mathrm{N}$ interaction in soil for which more investigation is needed.

The evaluation of the $\mathrm{N}$ uptake efficiency (NUE) showed a huge variation in the treatments among growth cycles (Figure 1). In the first GC, when biochar was recently incorporated to the soil,

Table 3 - Chlorophyll A, Chlorophyll B and ChloA/ChloB ratio of Indian mustard plants after growing in the copper contaminated soil treated with biochar from coconut shell (CSB), orange bagasse (OBB) and sewage sludge (SSB). Means followed by same letter (uppercase in a row; lowercase in a column) are not significantly different $(\mathrm{P}<0.05)$ for comparisons made within each crop cycle ( $\mathrm{n}=4$ per treatment)

\begin{tabular}{|c|c|c|c|c|c|c|}
\hline \multirow{2}{*}{ Rate of application } & CSB & OBB & SSB & CSB & OBB & SSB \\
\hline & -------------- & Srowth cy & ---------------- & \multicolumn{3}{|c|}{------------------------Growth cycle 2------------------------ } \\
\hline \multicolumn{7}{|c|}{----1 } \\
\hline 0 & 28.3Aa & $28.3 \mathrm{Aa}$ & $28.3 \mathrm{Aa}$ & 27.9Aa & 27.9Aa & $27.9 \mathrm{Aa}$ \\
\hline 30 & 27.1Aa & $27.2 \mathrm{Aa}$ & $29.1 \mathrm{Aa}$ & $24.0 \mathrm{Ab}$ & $23.2 \mathrm{Ab}$ & $23.8 \mathrm{Ab}$ \\
\hline 60 & 26.1Aa & $20.5 \mathrm{Bb}$ & $29.5 \mathrm{Aa}$ & $22.5 \mathrm{Ab}$ & $23.7 \mathrm{Ab}$ & $21.6 \mathrm{Ab}$ \\
\hline \multicolumn{7}{|c|}{ 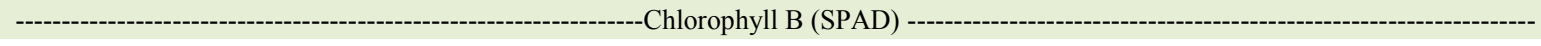 } \\
\hline 0 & 11.1Aa & 11.1Aa & 11.0Aa & $10.0 \mathrm{Aa}$ & $10.0 \mathrm{Aa}$ & $10.0 \mathrm{Aa}$ \\
\hline 30 & $9.42 \mathrm{ABa}$ & $8.12 \mathrm{Bb}$ & 11.1Aa & $6.57 \mathrm{Ab}$ & $6.90 \mathrm{Ab}$ & $8.00 \mathrm{Ab}$ \\
\hline 60 & 11.0Aa & $6.22 \mathrm{Bb}$ & $11.5 \mathrm{Aa}$ & $7.15 \mathrm{Ab}$ & $7.02 \mathrm{Ab}$ & $6.52 \mathrm{Ab}$ \\
\hline \multicolumn{7}{|c|}{ 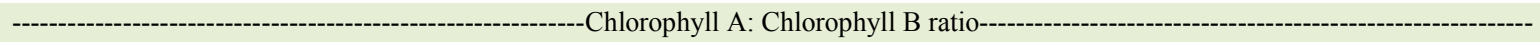 } \\
\hline 0 & $2.55 \mathrm{Aab}$ & $2.55 \mathrm{Ab}$ & $2.55 \mathrm{Aa}$ & $2.81 \mathrm{Ab}$ & $2.81 \mathrm{Aa}$ & $2.81 \mathrm{Aa}$ \\
\hline 30 & $2.88 \mathrm{Ba}$ & $3.34 \mathrm{Aa}$ & $2.64 \mathrm{Ba}$ & 3.70Aa & $3.38 \mathrm{ABa}$ & $3.00 \mathrm{Ba}$ \\
\hline 60 & $2.40 \mathrm{Bb}$ & $3.32 \mathrm{Aa}$ & $2.57 \mathrm{Ba}$ & 3.20Aab & $3.40 \mathrm{Aa}$ & $3.28 \mathrm{Aa}$ \\
\hline
\end{tabular}


Table 4 - Extractable concentrations of $\mathrm{P}, \mathrm{N}, \mathrm{K}$ and $\mathrm{Na}, \mathrm{pH}$ and $\mathrm{EC}$ in the copper contaminated soil treated with biochar from coconut shell (CSB), orange bagasse (OBB) and sewage sludge (SSB). Uppercase letters compare means among different biochars at the same dose. Lowercase letters compare means among different doses at the same biochar type $((\mathrm{P}<0.05)(\mathrm{n}=4$ per treatment $)$.

\begin{tabular}{|c|c|c|c|c|c|c|}
\hline \multirow{2}{*}{ Biochar type } & \multirow{2}{*}{ Rate of application } & $\mathrm{P}$ & $\mathrm{N}$ & $\mathrm{K}$ & $\mathrm{Na}$ & $\mathrm{pH}$ \\
\hline & & \multicolumn{5}{|c|}{ 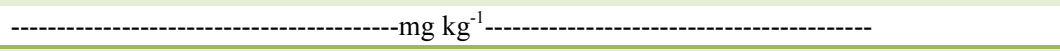 } \\
\hline \multirow{3}{*}{ CSB } & 0 & $44.1 \mathrm{Aa}$ & $2.96 \mathrm{Aa}$ & $50.1 \mathrm{Ac}$ & $0.09 \mathrm{Ac}$ & 4.79Abc \\
\hline & 30 & $40.1 \mathrm{Ba}$ & $2.57 \mathrm{Aa}$ & $170 \mathrm{Ab}$ & $120 \mathrm{Ab}$ & $5.60 \mathrm{Bb}$ \\
\hline & 60 & $44.8 \mathrm{Ca}$ & $3.38 \mathrm{Aa}$ & $338 \mathrm{Ba}$ & $262 \mathrm{Aa}$ & $6.50 \mathrm{Aa}$ \\
\hline \multirow{3}{*}{ OBB } & 0 & $46.4 \mathrm{Ab}$ & $2.96 \mathrm{Aa}$ & $50.1 \mathrm{Ac}$ & $0.09 \mathrm{Ab}$ & $4.79 \mathrm{Ab}$ \\
\hline & 30 & $67.0 \mathrm{Aa}$ & $1.70 \mathrm{Aab}$ & $302 \mathrm{Bb}$ & $20.7 \mathrm{Ba}$ & $6.26 \mathrm{Aa}$ \\
\hline & 60 & $72.0 \mathrm{Ba}$ & $1.60 \mathrm{Bb}$ & $660 \mathrm{Aa}$ & $28.0 \mathrm{Ca}$ & $7.06 \mathrm{Ba}$ \\
\hline \multirow{3}{*}{ SSB } & 0 & 43.4Ac & $2.96 \mathrm{Aa}$ & $50.1 \mathrm{Aa}$ & $0.09 \mathrm{Ac}$ & $4.79 \mathrm{Ab}$ \\
\hline & 30 & 74.7Ab & $2.14 \mathrm{Aa}$ & $59.4 \mathrm{Ca}$ & $28.7 \mathrm{Bb}$ & $5.74 \mathrm{Ba}$ \\
\hline & 60 & $97.8 \mathrm{Aa}$ & $0.65 \mathrm{Bb}$ & $19.9 \mathrm{Cb}$ & $82.6 \mathrm{Ba}$ & $5.84 \mathrm{Ca}$ \\
\hline
\end{tabular}

NUE varied from 0.57 to $0.80 \mathrm{~g} \mathrm{~N}$ plant $^{-1} \mathrm{~g} \mathrm{root}^{-1}$, and only the OBB reduced the plant efficiency in taking up N. The NUE was greatly reduced in the second GC in all treatments, including the control, varying from 0.08 to $0.18 \mathrm{~g} \mathrm{~N}$ plant $^{-1} \mathrm{~g}$ root $^{-1}$; however, this time all biochars caused reduction in the capacity of the plant to absorb N, except for CSB at $30 \mathrm{t} \mathrm{ha}^{-1}$ and OBB at $60 \mathrm{t} \mathrm{ha}^{-1}$. In the third GC, all biochars increased in approximately $80 \%$ the values of NUE, varying from 0.2 to $0.5 \mathrm{~g} \mathrm{~N}$ plant $^{-1} \mathrm{~g}$ root $^{-1}$, except the SSB when applied at a rate of $30 \mathrm{tha}^{-1}$.

\section{Effect of biochar in P nutrition}

The concentration of $\mathrm{P}$ in the shoot varied from 3.40 to $5.93 \mathrm{~g} \mathrm{~kg}^{-1}$ (Table 2). Biochar did not affect $P$ nutrition in Indian mustard, except for the CSB and OBB applied at a rate of 30t ha ${ }^{1}$, in the first GC, which increased $\mathrm{P}$ concentration in the aboveground biomass by approximately $72 \%$ and $61 \%$, respectively. These results are not likely related to the concentration of citric acid extractable $\mathrm{P}$ in the soil since application of CSB had no effect on $\mathrm{P}$ availability, regardless of the increase in soil $\mathrm{pH}$ caused by this biochar. In fact, application of OBB and SSB even increased the concentration of extractable $\mathrm{P}$ (Table 4), which could be related not only to the increase in soil $\mathrm{pH}$ but also to the concentration of $\mathrm{P}$ in the biochar (Table 1). A reasonable explanation for the lack of plant response related to $\mathrm{P}$ nutrition is the lower $\mathrm{P}$ requirement by Indian mustard plants which have higher demand for $\mathrm{N}$.

The plant efficiency in taken up P greatly varied among growth cycles (Figure 1), from 0.090.14g P plant ${ }^{-1}$ g root $^{-1}(\mathrm{GC} 1), 0.02-0.03 \mathrm{~g} \mathrm{P} \mathrm{plant}^{-1} \mathrm{~g}$ $\operatorname{root}^{-1}$ (GC2) and $0.02-0.10 \mathrm{~g} \mathrm{P}^{-1 a n t^{-1}} \mathrm{~g} \mathrm{root}^{-1}$ (GC3). CSB and OBB significantly $(\mathrm{P}<0.05)$ increased $\mathrm{P}$ uptake efficiency (PUE), regardless of the rate of application. SSB had low influence on the PUE.

\section{Effect of biochar on the N:P ratio in the plant}

Biochar addition to soil significantly $(\mathrm{P}<0.05)$ reduced the $\mathrm{N}$ :P ratio in the plants, regardless of the type and rate of application (Table 2). In the control treatment, N:P ratio varied from 7.23 to 9.04 across the three growth cycles whereas in the biochar treatments this variation was from 3.83 to 8.38 , with mean values of 5.85, 5.00 and, 6.24 for CSB, OBB and SSB, respectively, with lowest values mostly associated with the OBB. According to GARRISH et al. (2010), the $\mathrm{N}:$ P ratio is an effective tool to evaluate the availability of these nutrients to plants; values < 14 indicates $\mathrm{N}$ limitation whereas values $>16$ are a sign of $\mathrm{P}$ restriction to plant productivity. Therefore, our values confirmed $\mathrm{N}$ limitation in plants treated with biochar.

\section{CONCLUSION}

All biochars increased plant growth and reduced plant $\mathrm{N}$ concentration; however, the most effective was the orange bagasse biochar, indicating the need for a more cautious management of the $\mathrm{N}$ fertilization. Biochar increased plant $\mathrm{N}$ uptake efficiency which could explain the improved plant growth.

Even though biochar from orange bagasse and sewage sludge increased the availability of $\mathrm{P}$ in soil, no biochar influenced plant $\mathrm{P}$ nutrition, regardless of the increase in $\mathrm{pH}$ 


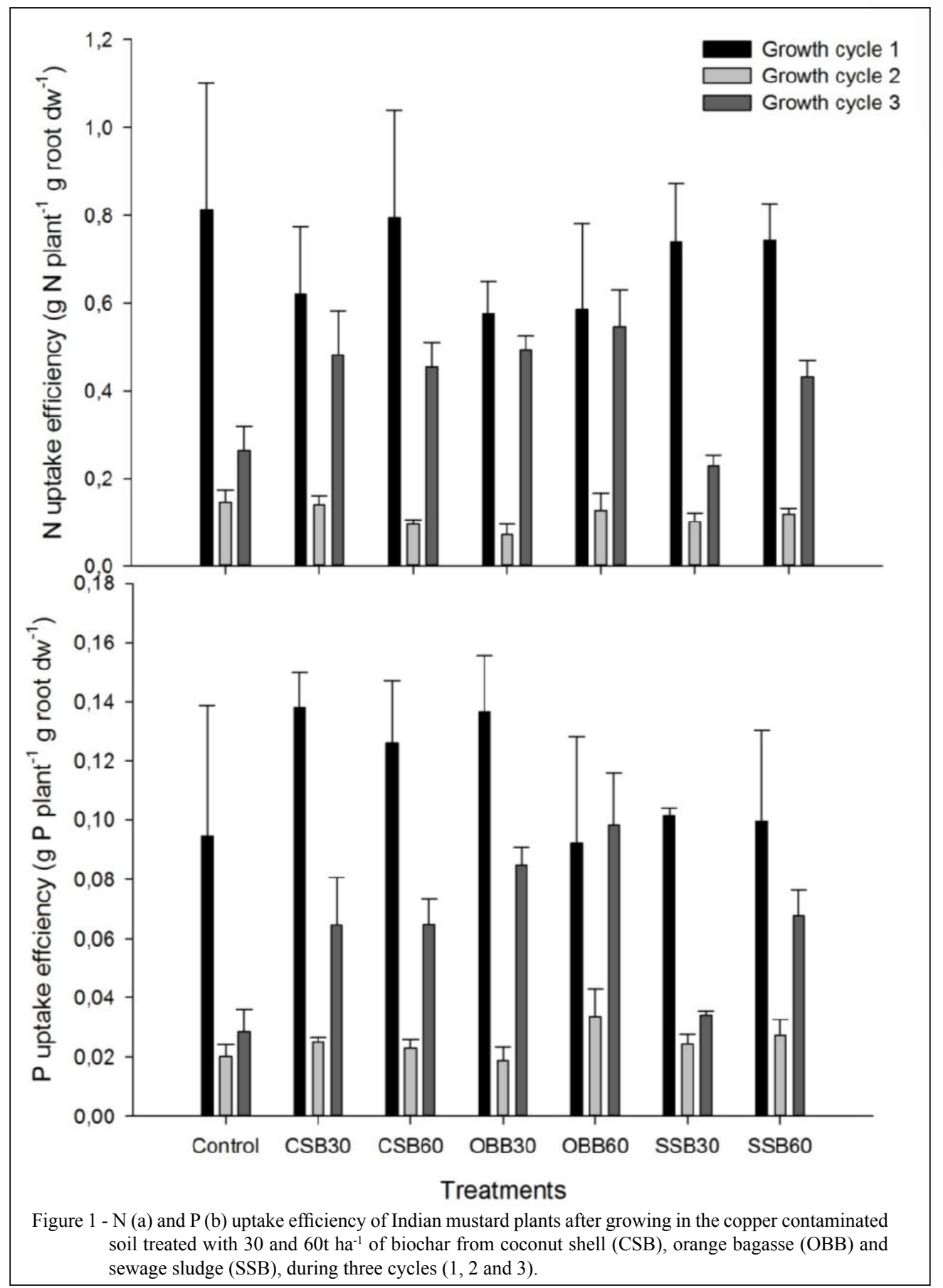

of this acidic soil. This was probably related to the plant species itself and its lower demand for $\mathrm{P}$ than for $\mathrm{N}$.

Considering that the plants had poor growth in the first cultivation cycle and; therefore, should not be taken into account, the effect of biochar on the plant $\mathrm{N}$ and $\mathrm{P}$ use efficiency seemed to improve as biochar aged in the soil from the second to the third cycle.

\section{ACKNOWLEDGMENTS}

We thank the Coordenação de Aperfeiçoamento de Pessoal de Nível Superior (CAPES) for supporting our research. 


\section{CONFLICTS OF INTEREST}

The authors declare no conflict of interest. The founding sponsors had no role in the design of the study; in the collection, analyses, or interpretation of data; in the writing of the manuscript, and in the decision to publish the results.

\section{AUTHORS' CONTRIBUTIONS}

The authors contributed equally to the manuscript.

\section{REFERENCES}

ABDELHAFEZ, A.A. et al. The black diamond for soil sustainability, contamination control and agricultural production. In: Huang, W.J. (ed.), Engineering applications of biochar. InTech, Chapter 2. 2017, 90p. Available from: $<$ http://www.intechopen.com/embed/engineering-applicationsof-biochar/biochar-the-black-diamond-for-soil-sustainabilitycontamination-control-and-agricultural-production $>$. Accessed: Oct. 26, 2017. doi: 10.5772; intechopen.68803.

ANTONIADIS, V. et al. Phosphorus availability in low-P and acidic soils as affected by liming and $\mathrm{P}$ addition. Communications in Soil Science and Plant Analysis, v.46, n.10, p.1288-1298, 2015. Available from: <http://dx.doi.org/10. 1080/00103624.2015.1033539>. Accessed: Oct. 20, 2017.

ARGENTA, G. et al. Leaf relative chlorophyll content as an indicator parameter to predict nitrogen fertilization in maize. Ciência Rural, v.34, n.5, p.1379-1387, 2004. Available from: <http://dx.doi.org/10.1590/S0103-84782004000500009>. Accessed: Jul. 23, 2017.

BREMNER, J.M. Nitrogen total. In: SPARKS, D.L. (ed). Methods of soil analysis. Part 3. Madison, America Society of Agronomy, Madison, 1996. p.1085-1121.

CLOUGH, T.J. A review of biochar and soil nitrogen dynamics. Agronomy, v.3, n.2, p.275-293, 2013. Available from: <https:// www.mdpi.com/2073-4395/3/2/275/pdf $>$. Accessed: Oct. 13, 2017. doi: 10.3390/agronomy 3020275 .

DAY, P. R. Particle fractionation and particle-size analysis. In: BLACK, C.A. et al. ed. Methods of Soil Analysis. Part 2. Chemical and Microbiological Properties. American Society of Agronomy, Madison, 1965. pp. 1367-1378.

DEENIK,J.L.; COONEY, M.J. The Potential Benefits and Limitations of Corn Cob and Sewage Sludge Biochars in an Infertile Oxisol. Sustainability, v.8, n.131, p.1-18, 2016. Available from: <https://www.mdpi.com/2071-1050/8/2/131/ pdf $>$. Accessed: Jun. 10, 2017. doi: 10.3390/su8020131.

FERREIRA, D.F. Sisvar: a computer statistical analysis system. Ciência e Agrotecnologia, v.35, p.1039-1042, 2011. Available from: <www.scielo.br/scielo.php>. Accessed: Oct. 10, 2017. doi: 10.1590/S1413-70542011000600001.

GARRISH, V. et al. Nitrogen to phosphorus ratio of plant biomass versus soil solution in a tropical pioneer tree, Ficus insipida. Journal of Experimental Botany, v.61, n.13, p.3735-3748, 2010 Available from: <https://www.ncbi.nlm.nih.gov/pmc/articles/ PMC2921206>. Accessed: Jul. 11, 2017. doi: 10.1093/jxb/erq183.
GOOD, A.G. et al. Can less yield more? Is reducing nutrient input into the environment compatible with maintaining crop production? Trends in Plant Science, v.9, n.12, p 597605, 2004. Available from: <https://www.ncbi.nlm.nih.gov/ pubmed/15564127>. Accessed: Oct. 10, 2017. doi: 10.1016/j. tplants.2004.10.008.

GROOT, C.C.et al. Interaction of nitrogen and phosphorus nutrition in determining growth. Plant and Soil, v.248, n.1, p.257-268, 2003. Available from: <jpkc.scau.edu.cn/soilless/ papers/upload/2012102722454790725.pdf>. Accessed: Oct. 12, 2017. doi: 10.1023 .

HAMMES, K.; SCHMIDT, M.W.I. Changes of biochar in soil. In: LEHMANN, J.; JOSEPH, S. Biochar for Environmental Management. Earthscan, London, 2009. pp 169-182.

KAMMANN, C. I. et al. Plant growth improvement mediated by nitrate capture in co-composted biochar. Scientific Reports, v.5, n.11080, p.1-13, 2015. Available from: <https://www. nature.com>scientificreports>articles $>$. Accessed: Oct 12, 2017. doi: $10.1038 /$ srep 11080 .

MOURATO, M. P. et al. Effect of heavy metals in plants of the genus Brassica. International Journal of Molecular Science. v.16, n.1, p.17975-17998, 2015. Available from: <https:// www.ncbi.nlm.nih.gov/pubmed/26247945>. Accessed: Sept. 9, 2017. doi: 10.3390/ijms 160817975 .

MURPHY, J. A.; RILEY, J. P. A modified single solution method for the determination of phosphate in natural waters. Analytica chimica acta, v. 27, n.1, p.31-36, 1962. Available from: <https://www.sciencedirect.com/science/ article/pii/S0003267000884445>. Accessed: Apr. 02, 2017. doi: 10.1016/S0003-2670(00)88444-5.

NGUYEN, T.T.N. et al. Effects of biochar on soil available inorganic nitrogen: A review and meta-analysis. Geoderma, v.288, n.1, p.79-96, 2017. Available from: <https://www. sciencedirect.com/science/article/pii/S0016706116307388>. Accessed: Oct. 25, 2017. doi: 10.1016.

RAHMAN, M.M. et al. Enhanced Accumulation of Copper and Lead in Amaranth (Amaranthus paniculatus), Indian Mustard (Brassica juncea) and Sunflower (Helianthus annuus). PLOS one, v.8, n.5, p. 1-9, 2013. Available from: <https://journals. plos.org/plosone/article?id=10.1371/journal.pone.0062941>. Accessed: Apr. 06, 2017. doi:10.1371.

RODRÍGUEZ-VILA, A. et al. Recovering a $\mathrm{Cu}$ mine soil using organic amendments and phytomanagement with Brassica juncea L. Journal of environmental management, v. 147, n.1, p.73-80, 2015. Available from: <https://www.ncbi.nlm. nih.gov/pubmed/25262389>_Accessed: Oct. 20, 2017. doi: 10.1016/j.jenvman.2014.09.011

SAARNIO, S. et al. Biochar addition indirectly affects $\mathrm{N}_{2} \mathrm{O}$ emissions via soil moisture and plant $\mathrm{N}$ uptake. Soil Biology and Biochemistry, v.58, n.1, p.99-106, 2013. Available from: <https://www.sciencedirect.com/science/ article/pii/S0038071712004142>. Accessed: Oct. 13, 2017. doi: $10.1016 /$ j.soilbio.2012.10.035.

SANTOS, H. G. et al. Sistema Brasileira de classificação do solo. 3. ed. Brasília: Embrapa Solos, 2013. 353 p. 
SILVA, M.I. et al. Potential impacts of using sewage sludge biochar on the growth of plant forest seedlings. Ciência Rural, v.47, n.1, p. 1-5, 2017. Available from: <www.scielo.br/scielo.php?script $=$ sci arttext\&pid=S0103-8478201700010040>. Accessed: Oct. 13, 2017. doi: 10.1590/0103-8478cr20160064.

SOIL SURVEY STAFF. Keys to Soil Taxonomy. 12. ed. Soil Survey Laboratory. National Soil Survey Center. USDA-NRCS, Lincoln, NE. 2014
THOMAS, G.W.Exchangeable cations. In: PAGE,A.L. etal.(Eds.), Methods of soil analysis: Chemical methods. Part 2: Chemical and Microbiological Properties. American Society of Agronomy, Madison, 1982. pp.159-165.

VANEK, S.; LEHMANN, J. Phosphorus availability to beans via interactions between mycorrhizas and biochar. Plant Soil, v.395, n.1, p.105-123, 2015. Available from: <https://link.springer.com/ article/10.1007/s11104-014-2246>. Accessed: Oct. 13, 2017. doi: $10.1007 / \mathrm{s} 11104-014-2246-\mathrm{y}$. 